Обзорная статья

УДК 621.892

DOI 10.18101/2306-2363-2021-1-28-42

\title{
ВЛИЯНИЕ ДОБАВОК МЕЛКОДИСПЕРСНЫХ ЧАСТИЦ МЕТАЛЛОВ НА ХАРАКТЕРИСТИКИ СМАЗОЧНЫХ МАТЕРИАЛОВ
}

\section{(C) Дамдинов Б. Б.}

доктор физико-математических наук, профессор

Сибирский федеральный университет

Красноярск, 660041, пр. Свободный, 79

Бурятский государственный университет им. Д. Банзарова

670000, г. Улан-Удэ, ул. Смолина, 24a

dababa@mail.ru

\section{(C) Митыпов Ч. М.}

магистрант

Сибирский федеральный университет

Красноярск, 660041, пр. Свободный, 79

chinamit@mail.ru

\begin{abstract}
Аннотация. Проведен обзор современных исследований в области влияния металлосодержащих мелкодисперсных компонентов на эксплуатационные характеристики смазочных материалов. Проведен анализ литературы по классификации, составу и свойствам металлосодержащих присадок, также показан механизм взаимодействия дисперсных компонентов. Исследования показали, что концентрацией и распределением данных компонентов можно управлять противоизносными, антиокислительными, антифрикционными и другими свойствами смазочных материалов.

Ключевые слова: смазочные материалы, вязкость, упругость, мелкодисперсные добавки, металлосодержащие присадки, полимер, жидкость, реологические свойства, суспензии наночастиц.
\end{abstract}

\section{Благодарности}

Работа выполнена при финансовой поддержке гранта РФФИ, Правительства Красноярского края и Красноярского краевого фонда науки в рамках проекта 20-42-240015 p_a

\section{Для цитирования}

Дамдинов Б. Б., Митыпов Ч. М. Влияние добавок мелкодисперсных частиц металлов на характеристики смазочных материалов // Вестник Бурятского государственного университета. Химия. Физика. 2021. Вып. 1. С. 28-42.

Смазочными материалами называются продукты органического и неорганического происхождения, которые вводятся между поверхностями трущихся элементов в узлах механизмов для уменьшения потерь на трение, износа, предотвращение заедания. Смазочный материал является одним из важнейших конструкционных материалов, во многом определяющий надежность узла трения. Оптимально подобранный смазочный материал позволяет в десятки и сотни раз снизить интенсивность трибологических процессов. По агрегатному состоянию они могут быть жидкими, пластичными, твердыми и газообразными. Наиболь- 
Дамдинов Б. Б., Митыпов Ч. М. Влияние добавок мелкодисперсных частиц металлов на характеристики смазочных материалов

шее распространение получили жидкие смазочные материалы (масла) и пластичные смазочные материалы (смазки).

Физико-химические свойства смазочных материалов, показывающие эксплуатационные характеристики. Противоизносные свойства определяют параметр интенсивности изнашивания деталей машин. Антифрикционные свойства определяют коэффициент трения сопряженных элементов в узлах. Противозадирные определяют параметр задирания, при котором разрушается смазочный слой и резко возрастает коэффициент трения и интенсивность изнашивания. Приработочные-параметр-время для стабилизации коэффициента трения в начальный период эксплуатации механизма. Противокоррозионные - свойства смазывающего материала, определяющие способность препятствовать коррозии металла. Антиокислительные - параметр, характеризующий старение (ухудшение) эксплуатационных свойств смазочного материала.

Применение современного высокопроизводительного и высокоточного оборудования и машин, многоцелевых станков (обрабатывающих центров) диктует необходимость повышения качества смазочного материала. Прочностные и эксплуатационные свойства инструмента и деталей узлов машин непосредственно зависят от физических и химических свойств смазывающего материала, структурных параметров, технологии изготовления и условий использования этих инструментов.

Использование перспективных компонентов и добавок в составе смазочных материалов позволит значительно повысить их эффективность, увеличить срок службы в узле трения и успешно решить задачи импортозамещения при их применении. Эффективным способом и технологические приемом, которые позволяют сохранять необходимые свойства, является за счет предварительное введение в состав смеси добавок нано или микрочастиц (оксидов, нитридов), которые играют роль ингибиторов, либо нанесения защитных слоев этих материалов на смазывающие материалы. Известно, что с повышением температуры вязкость масла уменьшается. Очевидно, что выгоднее всего применять масла, у которых кривая вязкости от температуры наименее зависима. Это важно, с одной стороны, для обеспечения максимальной несущей способности масляного слоя между трущимися деталями, с другой стороны, для нормальной эксплуатации машин, работающих на открытом воздухе при больших перепадах температур. Большие перепады температур имеют место в промышленности, где температура масла может колебаться от отрицательной до значений, превышающих сто градусов. Вязкость масла при колебании температуры в широких пределах в неблагоприятных случаях может настолько изменяться, что условия его работы будут различаться коренным образом, при этом в масле, как в дисперсионной среде образуются полидисперсные частицы износа, часть которых осуществляет седиментацию, а часть пребывает во взвешенном состоянии. Для улучшения состояния масел в них добавляют различных присадки [1-4].

Настоящая работа посвящена обзору влияния металлосодержащих мелкодисперсных компонентов на эксплуатационные характеристики смазочных материалов.

Менее изучены изменения в фазовом составе углеводородных смазочных масел, особенно в присутствии различных искусственных добавок (присадок) и 
их комбинаций, вводимых в масла для улучшения функциональных характеристик (антиокислительные свойства, противоизносное и антифрикционное действие и др.). Большинство из вводимых добавок обладают свойствами поверхностно-активных соединений, что способствует протеканию фазовых превращений в углеводородных средах и появлению новых специфических качеств рассматриваемых систем. Развитие и достижения последних лет позволяют взглянуть на процессы, протекающие в смазочных маслах, с позиций нанохимии, чтобы на основе этих подходов улучшить эксплуатационные свойства жидких углеводородных материалов.

\section{Общее положение}

Наряду с прогрессом в сфере исследования и увеличение мощностей современных механизмов и машин, создания и применения углеводородных смазочных масел, в этой области имеется ещё много нерешённых вопросов. В настоящее время возникает несколько проблем, таких как:

1. Уменьшение долговечности смазываемых узлов трения в связи со снижением несущей способности смазочного слоя в условиях нарастания интенсивности нагрузок и скоростей, а также большие перепады температур в современных машинах;

2. Быстрая переработка и потеря эксплуатационных свойств смазочного материала, что приводит к снижению длительности работы узлов без полной замены масла;

3. Экологические проблемы переработки и утилизации углеводородных смазочных материалов;

Для повышения эксплуатационных свойств смазочного материала предложено много полярно-активных и химически активных веществ, которые не решают проблемы окончательно. Решению данной проблемы посвящено большое количество работ, связанных с модифицированием смазочных масел, посредством целенаправленного введения в них антифрикционных, противоизносных и восстанавливающих дисперсных компонентов. Вместе с тем, в большинстве работ не учитывается наличие в узлах трения других видов дисперсных компонентов, влияющих на свойства смазочных материалов и взаимодействующих с модифицирующими дисперсными добавками.

В работе [4] наглядно показана классификация дисперсных компонентов в жидких углеводородных смазочных материалах (маслах) в зависимости от их происхождения (рис. 1).

В исследовательских целях мелкодисперсные частицы (добавки в смазочные материалы) подразделяют на несколько групп, из которых выделим некоторые.

В качестве противоизносных присадок обычно используют соединения, обладающие высокой поверхностной активностью по отношению к трущимся поверхностям, а также молекулы с большой длиной углеводородной цепи, надежно экранирующие силовое поле твердых тел. К ним относятся различные производные дитиофосфатных кислот, оказывающих также антиокислительное воздействие.

Противозадирные присадки являются соединения, обладающие значительной реакционной способностью, вследствие чего они выделяют такие элементы, 
Дамдинов Б. Б., Митыпов Ч. М. Влияние добавок мелкодисперсных частиц металлов на характеристики смазочных материалов

как хлор, серу, фосфор и их сочетания, а также некоторые другие элементы. Вступая в химическое взаимодействие с поверхностными слоями трущихся тел, они образуют модифицированные слои, надежно разделяющие эти тела, и препятствуют их схватыванию. Характерные противозадирные присадки - сульфиды и их производные, эфиры трихлорметилфосфоновой кислоты и т. д.

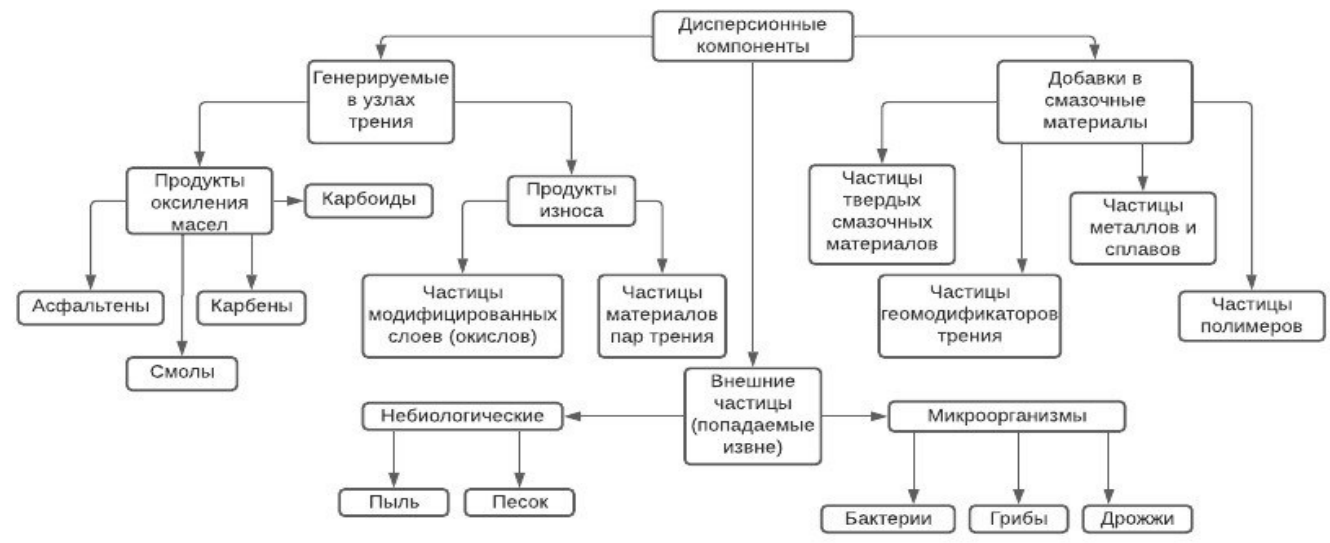

Рис. 1. Классификация дисперсных компонентов в углеводородных маслах (по Бреки)

Антиокислительные присадки замедляют старение масла. Окисление масел в целом ведёт к повышению их вязкости и к росту коррозионной активности, образованию углеродистых отложений, загрязнению фильтров, затруднению низкотемпературного запуска двигателей и к ухудшению прокачиваемости. К ним относятся дитиофосфаты и дитиокарбонаты металлов, бария и др.

Для снижения трения в масла вводят антифрикционные присадки - модификаторы трения. Как отмечено в недавнем обзоре современного развития модификаторов трения для жидких смазок [5], существует три вида таких модификаторов: органические модификаторы трения, металлоорганические соединения (главным образом, соединения молибдена) и нанопорошки. Применение микрои наночастиц различной природы (полимеры, металлы, керамика и др.) в качестве модификаторов трения широко изучается в настоящее время в трибологических центрах [6]. Такие порошковые добавки существенно повышают противоизносные свойства смазочных материалов и снижают коэффициент трения при высоких температурах и нагрузках. Уменьшение размера частиц приводит к увеличению способности их удерживания в масле без выпадения в осадок и к уменьшению интенсивности изнашивания, поэтому наноразмерные модификаторы являются наиболее эффективными среди порошковых модификаторов трения [6]. В качестве таких присадок используются различные маслорастворимые ПАВ, например, соли длинноцепочных органических кислот. Для масел, работающих в условиях высоких температур и нагрузок, используют высокотемпературные антифрикционные присадки: дитиофосфаты и дитиокарбонаты молибдена и др. Стоит отметить, что в некоторых случаях требуется, напротив, понизить 
антифрикционный эффект для увеличения коэффициента трения и предотвращения проскальзывания трущихся поверхностей.

Отдельно стоит выделить металлоплакирующие присадки, которые укрывают шероховатую поверхность новым микрослоем, состоящим из мягких металлов (чаще всего из меди), при этом уменьшается коэффициент трения. Металлоплакирующие присадки имеют большой существенный недостаток - это снижение твердости трущихся поверхностей. Очевидно, что компенсация износа мягкого защитного слоя будет происходить, только когда в масле достаточно «строительного материала» - той же меди, а потому использование таких составов требует регулярного ввода их в смазочное масло. В работе [7] на основе сравнительного анализа результатов физико-химических и трибологических исследований широкой номенклатуры металлоплакирующих присадок к смазочным материалам установлены их триботехнические характеристики, параметры формы и размера. Приведен обзор металлоплакирующих присадок к маслам, содержащих ультрадисперные порошки металлов.

Все они исследуются в качестве добавок к смазочным маслам и пластичным смазкам. Для каждой группы разрабатываются свои методы и свойства применения в смазочные материалы, которые рассматриваются несколько ниже.

\section{1. Молибден и его производные}

Введение в жидкий смазочный материал измельченных до нескольких сотен нанометров твердых частиц позволило получить даже при низких концентрациях стабильные коллоидные дисперсии. Среди наиболее распространенных добавок относятся соединения молибдена, в частности их сульфиды. Широко исследован дисульфид молибдена за счет высокой антифрикционной эффективности, но при этом следует отметить, что он нерастворим в жидких смазочных материалах, поэтому использовался только в пластичных и твердых смазках [8-10].

При добавлении дисульфида молибдена в смазочные материалы обе трущиеся металлические поверхности покрываются защитными слоями молекул дисульфида молибдена, которые свободно скользят относительно друг друга. Таким образом, исключается непосредственный контакт металла с металлом. Значительно уменьшается трение и перегрев деталей в зонах трения, особенно при экстремальных нагрузках, и замедляется износ металлических деталей. Суть в том, что серосодержащие комплексы Мо значительным образом уменьшают коэффициент трения трущихся поверхностей, благодаря наличию слоистой структуры, т.е. ведут себя как антифрикционные присадки. Иногда их еще называют модификаторами трения. Введение этих соединений в трансмиссионные масла приводит к заметной экономии топлива с одновременным снижением износа деталей и уменьшением расхода масла (рис. 2).

В литературе описан синтез и исследование большого числа органических, элементоорганических и металлокомплексных соединений, среди которых заслуженозанимают серосодержащие соединения молибдена, привлекшие к себе внимание благодаря своим высоким смазывающим и антиокислительным свойствам. Комплексы молибдена с азот-, серо- и фосфоросодержащими лигандами включены в коммерческие пакеты присадок к автомобильным смазочным маслам 
Дамдинов Б. Б., Митыпов Ч. М. Влияние добавок мелкодисперсных частиц металлов на характеристики смазочных материалов

и производятся рядом компаний, например Vanderbilt (USA), Chemtura (USA), Квалитет (Россия) [11].

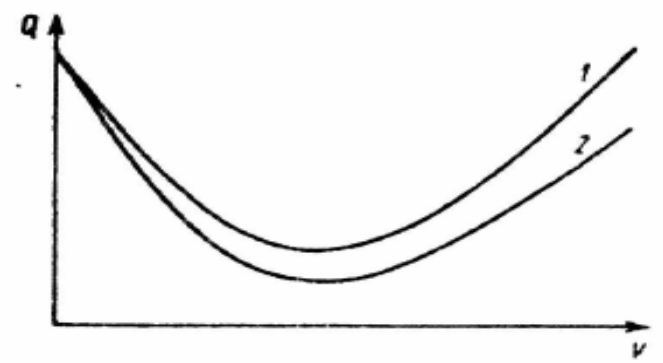

Рис 2. Изменение расхода бензина Q в двигателе внутреннегосгорания от частоты вращения коленчатого вала: 1 - масло без добавки;

2 - масло с добавкой 1,5\% дисульфида молибдена [12]

Как было написано ранее, дитиофосфаты и дитиокарбонаты (дитиокарбаматы) металлов обладают антиокислительными свойствами. Дитиофосфаты и дитиокарбаматы металлов являются эффективными антиоксидантами, причем эти соединения активно ингибируют окисление при повышенных температурах в отличие от многих традиционных антиокислителей, например, пространственно затрудненных фенолов или гетероциклических аминов [13]. Поэтому соединения дитиокарбаматов молибдена заслуживают особого интереса, так как присадки из этих веществ могут обладать не только антифрикционным свойством, но и антиокислительным. Антиокислительная активность дитиокарбаминовых комплексов молибдена обнаружена достаточно давно [14].

Подробно изучены кинетические закономерности ингибирующего действия двух комплексных соединений дитиокарбаматов молибдена: $\left[\left(\mathrm{n}-\mathrm{C}_{4} \mathrm{H}_{9}\right)_{2} \mathrm{NCS}_{2}\right]_{2} \mathrm{Mo}_{2} \mathrm{~S}_{4}$ и $\left[\left(\mathrm{n}-\mathrm{C}_{8} \mathrm{H}_{17}\right)_{2} \mathrm{NCS}_{2}\right]_{2} \mathrm{MoOS}$. Было показано, что антиокислительная активность значительно эффективней протекает в случае дитиокарбаматов молибдена по сравнению с более традиционным антиокислителем дитиокарбаматом цинка [15].

В работе [16] при исследовании композиций добавок показано, что поверхностно-модифицированные наночастицы трисульфида молибдена $\left(\mathrm{MoS}_{3}\right)$ и диалкилдитиофосфат цинка образуют синергическую смесь, которая демонстрирует высокую эффективность в снижении износа и коэффициента трения стали по стали, особенно при повышенных температурах (до $160^{\circ} \mathrm{C}$ ). Наночастицы сульфидов металлов, в частности молибдена, проявляют активность в снижении трения и износа при введении их в качестве добавок в смазочные масла в концентрации 0.1-2.0 мас.\%. При этом наночастицы $\mathrm{MoS}_{3}$ являются высокоактивными антифрикционными добавками, но обладают слабым противоизносным действием [17].

Необходимо отметить, что синтез комплексных соединений молибдена обычно осуществляется с использованием токсичных, экологически небезопасных соединений, таких как пентасульфид фосфора, алифатические амины и сероуглерод [17]. 
Большой обзор серосодержащих соединений молибдена в качестве присадок представлен в обзорной статье Паренаго [11]. Рассмотрены различные типы серосодержащих соединений молибдена, как модификаторов трения, обсуждаются вопросы их активности и механизма действия. Показана роль этих присадок как ингибиторов окисления углеводородных смазочных материалов. Обсуждаются экологические проблемы использования соединений тяжелых металлов в составе присадок к смазочным материалам. Представлены результаты последних лет по применению наноразмерных частиц сульфидов молибдена в качестве модификаторов трения.

\section{2. Медь и его производные}

Среди металлов, вводимых в смазочные материалы, наибольшее распространение получила медь и ее производные. Давно известно традиционное использование органических солей меди в качестве гомогенных катализаторов окисления углеводородов. Позднее была обнаружена способность органических соединений меди к антиокислительному действию и возможность усиления эффективности органических антиоксидантов путем координирования их функциональных групп с соединениями меди. Добавка незначительного количества комплексообразующего агента к смазкам заметно улучшает их смазочные свойства при трении медного сплава по стали, а введение готового комплекса меди - при трении стальных поверхностей, за счет образования серовитной пленки. Также впервые показана возможность применения галогенидов металлов, в частности меди, в качестве добавок к маслам для улучшения триботехнических свойств поверхностей трения. Образующийся слой меди содержит продукты механохимических превращений в щелочной среде, он довольно прочен и эластичен и может быть удален с поверхности только механической обработкой и травлением. В процессе работы на поверхностях трения стального вата и железного подшипника визуально наблюдалась тонкая медьсодержащая пленка. С учетом интенсивности изнашивания срок службы подшипников скольжения при использовании медьсодержащих смазочных материалов в 2...3 раза больше, чем обычно [18].

$\mathrm{B}$ научной литературе ряд работ посвящено изучению влияния добавок: $\mathrm{CuSO}_{4} \cdot 5 \mathrm{H}_{2} \mathrm{O}, \mathrm{CuS}, \mathrm{CuO}, \mathrm{Cu}_{2} \mathrm{O}, \mathrm{CuSO}_{4}, \mathrm{Cu}(\mathrm{OH})_{2}$, ультрадисперсного порошка меди, полученного электрохимических методом, - на антифрикционные свойства смазочных материалов. Показано, что введение ультрадисперсных медьсодержащих порошков в промышленные смазочные композиции улучшает триботехнические свойства основы: увеличивается предельная нагрузка задира и уменьшается коэффициент трения. Наибольшая эффективность добавок медьсодержащего порошка проявляется при больших нагрузках вблизи режима сухого трения [19].

Например, при добавлении $0.005 \%$ наночастиц оксида меди в масло SAE $10 \mathrm{~W}-30$ при испытании на экспериментальной установке с алюминиевым поршнем было замечено значительное снижение коэффициента трения [20]. Показано, что добавки наноразмерных медьсодержащих частиц, в отличие от промышленных медных порошков PRS (производство «Рanreac», Испания), значительно улучшают трибологические свойства композиционных смазочных материалов [21]. 
Дамдинов Б. Б., Митыпов Ч. М. Влияние добавок мелкодисперсных частиц металлов на характеристики смазочных материалов

Практически любые медьсодержащие добавки улучшают антифрикционные свойства основы за счет образования на поверхности трения тонкой медной пленки. Действие смазочного материала, наполненного медью, по-видимому, основано на вдавливании ее частиц в неровности поверхности трения и размазывании их по ней (металлоплакирующий эффект), в результате чего увеличивается фактическая площадь контакта, снижаются коэффициент трения и износ трущихся деталей. В случае использования соединений меди пленка получается более эффективной вследствие того, что взаимодействие меди с поверхностью трения происходит в момент "трибовосстановления". При этом, наиболее эффективной добавкой является оксид меди [19-22].

В заключении можно точно сказать, что смазочные среды, состоящие из масел с добавками меди, обеспечивают противоизносные и антифрикционные свойства пары трения сталь-сталь в условиях высокой нагрузки. Введение нанопорошков из меди позволяет несколько улучшить антифрикционные свойства смазочного материала.

\section{3. Цинк и его производные}

Цинк - белый, блестящий металл с хорошей электропроводностью. Обладает высоким антикоррозийным эффектом за счет образования на поверхности цинка оксидной пленки. Цинковые руды использовались для изготовления латуни в древние времена, но металлический цинк не производился до 13-го века. Пятьсот лет спустя этот элемент был вновь открыт в Европе. Он является хрупким при комнатной температуре, но податливым при температуре от 100 до $150^{\circ} \mathrm{C}$. Цинк используется преимущественно в качестве сплава с другими металлами.

Погодаевым Л.И. [22] выполнены комплексные исследования влияния добавок к пластичной смазке "Литол 24" мелкодисперсных порошков цинка, кадмия и бронзы на износостойкость и триботехнические свойства пар трения. Выявлено, что наибольшее влияние на усилие схватывания оказывает цинк, содержащийся в смазочной композиции в количестве 10 масс. \%. При таком же содержании цинка наблюдается наибольшее критическое давление (критическое усилие разрушения смазочной пленки). Как показало исследование [23], применение высокодисперсных порошков цинка в составе смазочных материалов является неэффективным, однако может способствовать уменьшению разброса долговечности механизмов и машин. В другой научной работе [24] показано, что цинкосодержащая смазка неэффективна, так как по сравнению с базовыми маслами, не наблюдалось повышение антифрикционных и противоизносных свойств. Механизм смазочного действия нанопорошков во всех режимах изнашивания не связан с образованием металлоплакирующей пленки. Физико-химические процессы, происходящие при трении в присутствии присадки, содержащей цинк, определяются химическим взаимодействием кислорода смазки с их частицами и с поверхностями трения и характером деформирования этих же частиц, находящихся на участках фактического касания. На поверхностях трения в присутствии добавок образуются вторичные структуры, представляющие собой участки натира, смешивания и окисления агломерированных и деформированных частиц наноприсадки и частиц износа. 
Особый интерес в реологии и трибологии смазочных материалов занимают соединения цинка. В работе [25] представлены результаты применения неорганического полимера фосфоровольфрамата цинка в качестве антифрикционной и противоизносной присадки, внесенной в вазелин и глицерин, использованных в качестве дисперсионной среды созданных смазочных материалов. Установлено, что введение в такие дисперсионные среды присадки данного типа улучшает трибологические свойства смазочных материалов без снижения эксплуатационных параметров

Одним из самых распространенных присадок содержащей цинк является диалкилдитиофосфат цинка (ZnDTP).Вещество представляют собой соединение, в котором цинк связан с анионом диалкилдитиофосфорной кислоты и обладают высокоэффективными антиокислительными и противоизносными свойствами.Это комплексное соединение начали применять в составе масел в начале 50ых годов и к настоящему времени в литературе имеются сотни работ, посвященных его строению и активности как антиокислительной, противоизносной и антикоррозионной присадки, наиболее важные для смазочного материаловедения свойства $[26,27]$. Входит в состав промышленных товарных присадок (ZD, ZDDP и т.д.).<smiles>[R2][R]([R2])(=S)S[Z10]SP([O])(O)=S</smiles>

Рис. 3. Структурная формула диалкилдитиофосфата цинка

Несмотря на значительное количество предложенных новых противоизносных присадок, трудно ожидать появления такого оптимального сочетания трибологических свойств в молекуле одной присадки, как это демонстрирует $\mathrm{ZnDTP}$. Кроме того, помимо противоизносных, противозадирных и антикоррозионных свойств эта присадка является также прекрасным антиокислителем. Показано, что, несмотря на значительное количество предложенных новых противоизносных присадок, трудно ожидать появления оптимального сочетания трибологических свойств в молекуле одной присадки, как это демонстрируют присадки на основе диалкилдитиофосфата цинка. Таким образом, решение проблем замены ZnDTP будет связано скорее всего с комбинацией присадок различных типов [28].

\section{4. Алюминий и его производные}

Наиболее широкое применение смазочных материалов на основе алюминий содержащей добавки получило так называемая алюминиевая смазка. Она состоит из диспергируемого в минеральном масле дистеарата алюминия в концентрации 10-20\%. Алюминиевые смазки, благодаря своей нерастворимости в воде и высокой липкости нашли применение как консервационные смазки для наружных частей механизмов, подверженных действию влаги. Смазки на основе комплексных алюминиевых мылах термо- и водостойки, обладают высокой механической стабильностью. Используется в механизмах, работающих в морской воде и со- 
Дамдинов Б. Б., Митыпов Ч. М. Влияние добавок мелкодисперсных частиц металлов на характеристики смазочных материалов

прикасающихся с ней. Смазка обладает защитно-антифрикционным свойством. Входит в состав технических смазок AMC-1 и АMC-3. В советское время изготовление алюминиевых смазок было ограничено, в настоящее время обретает популярность [29-31].

Чистый алюминий может использовать в качестве пластичной матрицы в составе смазочного композита с добавлением высокодисперсной добавки. В рамках работы [32] получен композиционный антифрикционный материал $\mathrm{Al}-\mathrm{Al}_{2} \mathrm{O}_{3}-\mathrm{C}$ со слоистой структурой из промышленного алюминиевого порошка марки ПАП2 реакционным спеканием порошковых заготовок в режиме фильтрационного горения. Разработанный материал характеризуется малым коэффициентом трения скольжения $(0,17)$ и, практически, полным отсутствием износа благодаря сочетаниювысоких показателей рекомендован для использования в триботехнических устройствах, к которым предъявляется требование сочетания высоких показателей весовой эффективности и трибологических свойств.

В настоящее время существует множество смазочных материалов, полученных путем загущения комплексными алюминиевыми мылами. Благодаря водной устойчивости и химической нейтральности, а также экологической безопасности применяется в медицине, пищевой промышленности, даже в косметических средствах. Также стоит отметить такое свойство как адгезия, благодаря которому смазка обладает высокой липкостью, что позволяет смазке удерживаться в узлах механизмов под прямым воздействием внешних факторов.

Алюминиевые порошки и пудры используют в смазочных материалах, применяемых при обработке металлов для смазки валков горячей обработки металлов, прессформ и прессующего узла машин литья под давлением, кристаллизаторов установок непрерывного литья слитков из алюминия и его сплавов, фильер для волочения проволоки, как пластификатор для брикетирования металлических порошковых материалов. Известно о применении порошка сплава Al-Zn в качестве наполнителя смазок при холодной объемной штамповке. Алюминиевую пудру без добавок используют в качестве смазки при изготовлении керамических деталей методом сухого прессования для уменьшения износа пресс-форм, получения высокой плотности прессовки, снижения усилия прессования. Существуют способы регенерации смазочных масел с использованием алюминиевых порошков. Порошок смешивают с маслом, смесь нагревают до $100^{\circ} \mathrm{C}$, затем удаляют суспензированные вещества фильтрацией или осаждением, масло обесцвечивают и регенерируют обработкой молотым гипсом [33].

В работе [34] методом акустической эмиссии в ультразвуковом диапазоне частот (20-300 кГц) проведены измерения интегральных показателей трения и их сопоставительный анализ для пары трения металл - металл со смазкой в виде индустриального масла, наполненного наноструктурированными порошками на основе алюминия. Оценено влияние присадки на смещение участка сухого трения на кривых зависимостей показателя трения от давления в зоне контакта. Выявлен наноструктурированный образец на основе алюминиевой пудры ПАП-2, содержащей на поверхности двухкомпонентную нанопленку катионных ПАВ, который улучшает антифрикционные характеристики индустриального масла И20 в 4-7 раз. Также в статье показаны физические представления о механизме действия присадок на антифрикционные свойства масла. 
Наличие алюминий содержащей композиции ведет к повышению контактной выносливости тел качения в 1,3 раза по сравнению с базовыми смазочными материалами. Наличие на контактирующих поверхностях мягкой пленки, в состав которой входит алюминий особой структуры и свойств, лежащий на упроченной подложке, обеспечивает локализацию процесса трения в тончайшем поверхностном слое и препятствует вовлечению в процесс деформации более глубоких слоев металла. При этом низкий коэффициент трения и высокая износостойкость подвижных сопряжений как при скольжении, так и качении, связаны в основном с наличием в смазочном материале алюминий содержащей композиции, которая обеспечивает формирование антифрикционной и противоизносной пленки, а также расширяет диапазон удельных нагрузок, при которых узел трения работает в нормальном режиме [35].

В современном мире развитие алюминий содержащих смазок набирает большой темп, благодаря низкой стоимости сырья и экологической безопасности по сравнению с другими смазочными материалами.

\section{5. Вольфрам и его соединения}

Как было отмечено ранее, сульфиды некоторых металлов обладают высокими антифрикционными свойствами.

Наночастицы дисульфида вольфрама, как один из материалов в ряду дихалькогенидов переходных металлов, сфероидальной формы являются чрезвычайно полезными твердосмазочными материалами [36]. Предварительные испытания $\mathrm{WS}_{2}$ наночастиц проводили на специальном стенде по схеме «вал- кольцо». Кольца были изготовлены из порошкового материала с пористостью поверхностных слоев около 14-16\%. Средний размер частиц составлял 80 нм. Вал был изготовлен из стали $40 \mathrm{X}$. Импрегнация наночастиц осуществлялась через масляную суспензию под действием ультразвука. Коэффициент трения, полученный в результате испытания, имел значения ниже 0,08 . Таким образом, наночастицы дисульфида вольфрама имеют огромный потенциал как смазочные материалы для узлов трения, работающих в экстремальных условиях [37].

В подтверждение предыдущей работы, экспериментально установлено, что наноразмерные дихалькогениды вольфрама $\mathrm{WS}_{2}$ и $\mathrm{WSe}_{2}$ повышают предельную нагрузочную способность смазочного слоя соответственно на 20-44\%, в 3 раза; уменьшают диаметр пятна износа соответственно на 12-30\%, 15\%; уменьшают граничное трение соответственно на $41-44 \%$, в 2 раза, относительно масла, не содержащего добавки, что говорит об улучшении антифрикционных свойств и несущей способности смазочного слоя. Введение антифрикционных наночастиц $\mathrm{WSe}_{2}$ в смазочный слой способствует снижению силы трения скольжения подшипникового шара по диску на $18-53 \%$. В связи с этим смазочная композиция, содержащая диселенид вольфрама, может быть полезна в условиях заклиниваний, проскальзывании тел качения в нормальных условиях эксплуатации (из-за погрешностей изготовления тел качения и других элементов), в условиях изменения формы элементов подшипника в результате выкрашивания, бринеллирования, истирания, а также в условиях воздействия абразивных частиц $[4,38]$.

В работе [39] проводилось исследование более сложного соединения, содержащего вольфрам. В качестве таких присадок были выбраны полимерные 
Дамдинов Б. Б., Митыпов Ч. М. Влияние добавок мелкодисперсных частиц металлов на характеристики смазочных материалов

фосфаты метафосфатного состава общей формулой $\left[\mathrm{MePO}_{3}\right]_{\mathrm{n}}$, способные встраивать в свою структуру тетраэдрические фрагменты $\mathrm{WO}_{4}$. Вариации состава позволяют целенаправленно управлять свойствами полимерных фосфатов, которые можно использовать в качестве присадок к смазочным материалам. Исследуемой присадкой являлся фосфоровольфрамат лития $\mathrm{LiPWO}_{6}$. Триботехнические испытания и исследования поверхности трибоконтакта показали существенное улучшение физико-химических и трибологических характеристик смазочной композиции с синтезированными присадками по сравнению с базовым смазкочным материалом, что позволяет разработать широкий спектр высокоэффективных смазочных материалов с наполнителями и нанодобавками из фосфоровольфраматов металлов для трибосистем. Также большим плюсом является что, кислородные соединения вольфрама (VI), в том числе и фосфоровольфраматы, по санитарно-гигиеническим нормам относятся к IV классу опасности (токсичности) аналогично хлориду натрия -поваренной соли, т.е. являются малоопасными соединениями [39-41].

\section{Заключение}

Обзор литературных данных по металлосодержащим мелкодисперсным добавкам (присадкам) в последнее время показывает, что развитие исследований во многом сводится к модификации синтетическими методами основных классов соединений, известных уже с конца прошлого столетия (сульфиды, дитиоалкилдитиофосфаты и т.д.). Более широко стали использоваться различные комбинации присадок из нескольких типов соединений, проявляющих синергический эффект. С развитием экспериментальной техники (сканирующей и просвечивающей электронной микроскопии, комбинационной спектроскопии и т. п.) проведены обширные исследования по изучению механизма действия присадок, по определению природы и свойств трибослоев на поверхности трения. Однако ряд вопросов данной проблемы требует дальнейших более глубоких исследований, в особенности в условиях высокой интенсивности нагрузок и температур [42, 43], а также синтез и экологическую стабильность применяемых металлосодержащих присадок. С другой стороны актуальной задачей остается повышение износостойкости и антифрикционности материалов самих узлов трения и машин в жестких и экстремальных условиях эксплуатации (высокие и сверхнизкие температуры, инертная и агрессивная среда, невозможность применения смазочных материалов).

Можно полагать, что дальнейшее работы, посвященные к дисперсным металлосодержащим добавкам, приведет к дальнейшему прогрессу в области получения и применения различных видов присадок с удовлетворительными эксплуатационными характеристиками.

\section{Литература}

1. Сандитов Д. С., Бартенев Г. М. Физические свойства неупорядоченных структур. Новосибирск: Наука, 1982. 259 с.

2. Бакунин В. Н., Кузьмина Г. Н., Паренаго О. П. Наноразмерные структуры в углеводородных смазочных материалах // Российский химический журнал. 2003. Т. 47, № 2. C. $45-50$. 
3. Бреки А. Д., Васильева Е. С., Максимов М. Ю., Чулкин С. Г. Исследование нагрузочной способности смазочных композиций с наночастицами $\mathrm{WS}_{2}$ и $\mathrm{WSe}_{2}$ для железнодорожных втулок // Вопросы материаловедения. 2012. Т. 70, № 2. С. 109-149.

4. Бреки А. Д. Триботехнические свойства модифицированных смазочных масел: автореферат диссертации на соискание ученой степени кандидата технических наук. Санкт-Петербург, 2011. 20 с.

5. Tang Zh., Lia Sh. A review of recent developments of friction modifier for liquid lubricants (2007-present) // Curvent Opinion in Solid State and Materials Science. 2014. V. 18, № 3. Р. 119-139.

6. Пучков В. Н., Заскалько П. П. Исследования влияния добавок наноструктурированных материалов на трибологические свойства смазочных масел // Трение и смазка в машинах и механизмах. 2010. № 11. С. 25-30.

7. Нгуен Х. Идентификация триботехнических характеристик наноразмерных металлоплакирующих присадок: автореферат диссертации на соискание ученой степени кандидата технических наук. Ростов на Дону, 2015. 22 с.

8. Groszek R. Preferential Adsorption of Compounds with Long Methylene Chains on Cast Iron, Graphite, Boron Nitride, and Molybdenum Disulfide // ASLE Transactions. 1966. V. 9. P. 67-75.

9. Sebnik R. F. Molybdenum Disulfide in Grease, Oil Dispersion and Solid Film // NLGI Spokesman. 1993. V. 57. P. 96-106.

10. Epshteyn Y., Risdon T.J. Molybdenum Disulfide in lubricant applications - a review // 12 Lubricating Grease Conference NLGI. India. 2010. P. 143-144

11. Займовская Т. А., Кузьмина Г. Н., Паренаго О. П. Серосодержащие соединения молибдена как высокоэффективные присадки к смазочным материалам (Обзор) // Нефтехимия. 2017. Т. 57, № 4. С. 367-379.

12. Чичинадзе А. В., Хебды М. Справочник по триботехнике: в 3 т. Москва: Машиностроение, 1990. $420 \mathrm{c}$.

13. Brooks L. A. The chemistry of thiazoles and dithiocarbamates as antioxidants // Rubber Chem. Technol. 1963. V. 36. P. 887-910.

14. Philip C. H. Mitchell Oil-soluble MO-S compounds as lubricant additives // Wear. 1984. V. 100. P. 281-300.

15. Займовская Т. А., Кузьмина Г. Н., Санин П. И., Паренаго О. П. Исследование антиокислительной эффективности дитиокарбаматов молибдена кинетическим методом // Нефтехимия. 1991. Т. 31, № 4. С. 521-527.

16. Бакунин В. Н. Наноразмерные структуры в углеводородных смазочных материалах: автореферат диссертации на соискание ученой степени кандидата химических наук. Москва, 2007. 43 с.

17. Бордубанова Е. Г., Лядов А. С., Оганесова Э. Ю., Паренаго О. П. Синтез и трибологическое поведение наночастиц сульфидов металлов, полученных термосольволизом серосодержащих прекурсоров // Нефтехимия. 2019. Т. 59, № 5. С. 580-588.

18. Гаркунов Д. Н. Металлоплакирующие смазочные материалы // Качество и жизнь. 2014. Т. 1, № 1. С. 38-44.

19. Тесакова М. В., Парфенюк В. И., Годлевский В. А. Триботехнические характеристики смазочных композиций на основе ультрадисперсных медьсодержащих порошков, полученных электрохимическим методом // Трение и смазка в машинах и механизмах. 2010. № 2. С. 22-26.

20. Годевский В. А., Парфенюк В. И., Тесакова М. В. Влияние добавок ультрадисперсных наноразмерных медьсодержащих порошков на трибологические свойства промыщленных смазок // Электронная обработка материалов. 2008. № 8. С. 56-62.

21. Ashida M., Hisham S., Awang N. W. and other. Copper (II) oxide nanoparticles as additve in engine oil to increase the durability of piston-liner contact // Fuel. 2018. V. 212. P. $656-667$. 
Дамдинов Б. Б., Митыпов Ч. М. Влияние добавок мелкодисперсных частиц металлов на характеристики смазочных материалов

22. Погодаев Л. И., Кузьмин В. Н., Дудко П. П. Повышение надежности трибосопряжений. Санкт-Петербург: Академия транспорта РФ, 2001. 304 с.

23. Татулян А. А., Цветков Ю. Н. Влияние добавок высокодисперсных порошков твердых смазочных материалов в смазку на характеристики подшипников качения // Вестник государственного университета морского и речного флота им. Адмирала С. О. Макарова. 2013. Т. 21, № 2. С. 86-94.

24. Беляев С. А. Изучения процесса изнашивания конструкционных сталей в среде жидкой смазки с добавками нанопорошков пластичных металлов: автореферат диссертации на соискание ученой степени кандидата технических наук. Новокузнецк, 2007. 19 с.

25. Савенкова М. А., Воляник С. А., Шехов В. П. и др. Повышение трибологических характеристик смазочных материалов введением присадки фосфоровольфрамата цинка // Сборка в машиностроении, приборостроении. 2020. № 9. С. 415-418.

26. Spikes H. The history and mechanisms of ZDDP // Tribol. Lett. 2004. V. 17. P. 469-489.

27. Allyson M. Barnes, Keith D. Bartle, Vincent R. A., Thibon A. Review of zincdialkyldithiophosphates (ZDDPS): characterisation and role in the lubricating oil // Tribology International. 2001. P. 389-395.

28. Паренаго О. П., Оганесова Э. Ю., Лядов А. С., Шараева А. А. Современное состояние и перспективы синтеза экологически безопасных противоизносных присадок к смазочным материалам (Обзор) // Журнал прикладной химии. 2020. Т. 93, № 11. С. 1523-1533. $368 \mathrm{c}$.

29. Гуреев А. А., Фукс И. Г., Лашхи В. Л. Химмотология. Москва: Химия, 1986.

30. Меркурьев Г. Д., Елисеев Л. С. Смазочные материалы на железнодорожном транспорте. Справочник. Москва: Транспорт, 1985. 255 с.

31. Курчик Н. Н., Вайншток В. В., Шехтер Ю. Н. Смазочные материалы для обработки металлов резанием. Москва: Химия, 1972. 312 с.

32. Иванов Д. А., Иванов А. В., Шляпин С. Д. Антифрикционный композиционный материал $\mathrm{Al}-\mathrm{Al}_{2} \mathrm{O}_{3}-\mathrm{C}$ полученный из алюминиевого порошка ПАП-2 // Технология легких сплавов. 2012. № 2. С. 78-86.

33. Гопиенко В. Г., Петрович С. Ю., Черепанов В. П. и др. Металлические порошки алюминия магния, титана и кремния. Санкт-Петербург: Изд-во Политехн. ун-та, 2012. 356 с.

34. Быстров Д. С., Фокин А. С., Пантюшин И. В., Базалева В. В., Сырков А. Г. Влияние наноструктурированных добавок металлов на антифрикционные свойства индустриального масла // Записки горного института. 2009. Т. 182. С. 227-230.

35. Додонова Д. А., Пичугин В. Ф., Лаптев Д. В. Исследование антифрикционных и противоизносных свойств алюминийсодержащей смазочной композиции // Трение и смазка в машинах и механизмах. 2010. № 2. С. 27-33.

36. Rapoport L., Bilik Yu., Feldman Y., Homyonfer M., Cohen S.R. and Tenne R. Hollow nanoparticles of $\mathrm{WS}_{2}$ as potential solid-state lubricants // Nature. 1997. V. 387. P. 791-793.

37. Васильева Е. С., Игнатьев М. Б., Ковалев Е. П., Ли Д. В. Газофазный синтез дисперсных частиц дисульфида вольфрама и их применения // Вестник новгородского государственного университета. 2008. № 46. С. 7-10.

38. Бреки А. Д., Медведева В. В., Фадин Ю. А. и др. Влияние смазочного композиционного материала с наночастицамидиселенида вольфрама на трение в подшипниках качения // Изв. Тульского госуниверситета. Технические науки. 2015. Т. 11, № 1. С. 171-180.

39. Колесников В. И., Мигаль Ю. Ф., Савенкова М. А., Солодовникова Д. Н. Создание экологически безопасных смазочных материалов с многофункциональными присадками // Экологический вестник научных центров ЧЭС. 2014. № 3. С. 38-44.

40. Колесников В. И., Мигаль Ю. Ф., Савенкова М. А., Солодовникова Д. Н. Фосфоровольфрамат лития - эффективная присадка к пластичным смазкам для тяжелонагруженных трибосопряжений // Трибология и надежность: сборник научных трудов XI 
Международной конференции. Санкт-Петербург: Петербургский государственный университет путей сообщения, 2011. С. 148-150.

41. Мясникова Н. А., Мантуров Д. С., Лебединский К. С., Новиков Е. С. Экспериментальное изучение свойств смазочных композиций с присадками на основе фосфоровольфраматов // Вестник РГУПС. 2018. № 1. С. 21-27.

42. Damdinov B., Dembelova T., Badmaev B., Barnakov Yu. Structural Research of Nanoparticles Dispersions // Solid State Phen. 2019. V. 288. Р. 130-134.

43. Козлов Г. В., Сандитов Д. С. Ангармонические эффекты и физикомеханические свойства полимеров. Новосибирск: Наука, 1994. 261 с.

Статья поступила в редакцию 20.11.2020; одобрена после рецензирования 28.01.2021; принята к публикации 29.01.2021.

\section{INFLUENCE OF FINELY DISPERSED METAL PARTICLES ADDITIVES ON LUBRICANTS CHARACTERISTICS}

\section{Damdinov B. B.}

Doctor of Physical and Mathematical Sciences, Professor

Siberian Federal University

660041, Krasnoyarsk, pr. Svobodny, 79

Buryat State University

670000, Ulan-Ude, st. Smolina, 24a

dababa@mail.ru

Mitypov Ch. M.

Master's student

Siberian Federal University

660041, Krasnoyarsk, pr. Svobodny, 79

chinamit@mail.ru

Abstract. A review of modern research in the field of the influence of metal-containing finely dispersed components on the performance characteristics of lubricants is carried out. The analysis of the literature on the classification, composition and properties of metal-containing additives is carried out, and the mechanism of interaction of dispersed components is also shown. Studies have shown that the concentration and distribution of these components can be controlled by antiwear, antioxidant, antifriction and other properties of lubricants.

Keywords: lubricants, viscosity, elasticity, finely dispersed additives, metal-containing additives, polymer, liquid, rheological properties, nanoparticle suspensions

\section{Acknowledgments}

This work was financially supported by RFBR, Government of Krasnoyarsk Region, Krasnoyarsk regional scientific foundation, Grant no. 20-42-240015 r_a

\section{For citation}

Damdinov B. B., Mitypov Ch. M. Influence of Additives of Dispersed Metal Particleson Characteristics of Lubricants // Bulletin of Buryat State University. Chemistry. Physics. 2021; 1: 28-42 (In Russ.).

The article was submitted 20.11.2020; approved after reviewing 28.01.2021; accepted for publication 29.01.2021. 